NOTE

\title{
Oxygen consumption of a single embryo/planula in the reef-building coral Acropora intermedia
}

\author{
N. Okubo ${ }^{1,5, *}$, H. H. Yamamoto ${ }^{2}$, F. Nakaya ${ }^{3}$, K. Okaji ${ }^{4}$ \\ ${ }^{1}$ Graduate School of Environment and Information Sciences, Yokohama National University, Tokiwadai 79-2, Hodogaya, \\ Yokohama 240-8501, Japan \\ ${ }^{2}$ Okinawa Churaumi Aquarium, Motobu-cho, Okinawa 905-0206, Japan \\ ${ }^{3}$ Graduate School of Humanities and Science, Ochanomizu University, Bunkyo-ku, Tokyo 112-8610, Japan \\ ${ }^{4}$ CoralQuest Inc., Asahicho 1-34-10, Atsugi, Kanagawa 243-0014, Japan
}

${ }^{5}$ Present address: Japan Society for the Promotion of Science/Seto Marine Biological Laboratory, Field Science Education and Research Center, Kyoto University, Shirahama, Nishimuro, Wakayama 649-2211, Japan

\begin{abstract}
O}_{2}$ consumption of a single embryo/planula at each developmental stage was monitored in the reef-building coral Acropora intermedia using an optical $\mathrm{O}_{2}$-sensing system with our original micro-chamber system $(6.28 \mu \mathrm{l})$. The lowest rate of $\mathrm{O}_{2}$ consumption was observed in unfertilized eggs. After fertilization, $\mathrm{O}_{2}$ consumption increased and remained constant until the prawn chip blastula stage. However, $\mathrm{O}_{2}$ consumption began to increase again during the bowl-shaped blastula stage, which involves the formation of 2 germ layers and corresponds to the beginning of gastrulation. The rate of $\mathrm{O}_{2}$ consumption peaked during the teardrop-shaped planula stage. During this stage planulae are able to swim actively, especially in the vertical plane, so an increase in energy consumption during this stage is to be expected. $\mathrm{O}_{2}$ consumption began to decrease gradually $5 \mathrm{~d}$ after spawning. At this stage, the larvae frequently touched the substrate with their concave aboral end, which features numerous spirocysts required for substrate attachment. When the planulae began to settle, $7 \mathrm{~d}$ after spawning, the rate of $\mathrm{O}_{2}$ consumption dropped to that of unfertilized eggs, suggesting that the planulae slowly use stored energy for crawling/settlement behavior and/or post-settlement growth and survivorship.
\end{abstract}

KEY WORDS: Development · Dispersal $\cdot$ Energy $\cdot$ Larva $\cdot$ Lecithotrophic $\cdot$ Metabolism $\cdot$ Recruitment Settlement-competency period

\section{INTRODUCTION}

In marine invertebrates, larval dispersal and recruitment affect the distribution and abundance of adult populations (Underwood \& Keough 2001). The dispersal potential of planktonic larvae is physically dependent upon ocean currents and biologically dependent upon buoyancy in the water column (Morgan 1995), larval behavior (Harii \& Kayanne 2003), survivorship (Isomura \& Nishihira 2001), and the length of the settlement-competency period (Nozawa \& Harrison
2005). In environments in which food is scarce, these biological factors are affected by the egg's energy content, in the form of lipids, proteins, and carbohydrates (Holland 1978, Chia et al. 1984), and by the metabolic rate at which these reserves are consumed during development (Richmond 1987, Bryan 2004). In coral, temporal changes in the lipid content have been reported in larvae of spawning species (Harii et al. 2007); however, little information is available regarding energy consumption (Richmond 1987, Ben-DavidZaslow \& Benayahu 2000). The metabolic rate at each 
developmental stage is an important index for understanding larval dispersal and recruitment; such data indicate when the larvae use energy and how they allocate the maternally derived energy for dispersal potential, larval fitness, and post-settlement growth and survival (Richmond 1987, Hoegh-Guldberg \& Manahan 1995).

A number of studies have examined the energetics of the development of planktotrophic and lecithotrophic species of sea urchin and abalone (Crisp et al. 1985, Marsh et al. 1999, Bryan 2004). However, the most common method of measuring $\mathrm{O}_{2}$ consumption (i.e. an electrode) is unsuitable for small chamber volumes because the sensor itself consumes dissolved $\mathrm{O}_{2}$ to measure the density of $\mathrm{O}_{2}$ (Clark 1956). In addition, because numerous embryos or planulae compete with each other to consume excess energy in the chamber, the $\mathrm{O}_{2}$ consumption rate per embryo or planula derived from this method is not reliable for analyzing the transitions between developmental stages. Here, we present data for $\mathrm{O}_{2}$ consumption of a single coral embryo/planula at each developmental stage using an optical $\mathrm{O}_{2}$-sensing system. This system has several advantages: no $\mathrm{O}_{2}$ consumption, no membrane or electrolytes required (i.e. easy maintenance), high sensitivity and stability, and an adequate chamber volume (Nakaya et al. 2003, 2005). No previous data are available for $\mathrm{O}_{2}$ consumption in coral embryos or planulae using the technique described here.

\section{MATERIALS AND METHODS}

We collected 9 fragments of Acropora intermedia (Wallace \& Dai 1997) from 3 large colonies at a depth of 2 to $4 \mathrm{~m}$ from the back-reef in Bise, Okinawa $\left(26^{\circ} 3^{\prime} 52^{\prime \prime} \mathrm{N}, 127^{\circ} 5^{\prime} 30^{\prime \prime} \mathrm{E}\right)$. All specimens were cultured together in a large tank $1.5 \mathrm{~m}$ high and $20 \mathrm{~m}^{2}$ in area). To prevent stress from the orientation of attachment, each fragment was secured vertically in a PVC pipe attached to a plastic plate (Okubo et al. 2005). All branches spawned on 16 and 17 June 2007; the gametes that were spawned on 17 June were used in the experiment. To collect sperm and egg bundles from a single colony, when the bundles appeared, the fragments were removed from the large tank and placed in separate tanks. After spawning, bundles from a single colony were placed in Petri dishes and broken by pipetting to collect unfertilized eggs. For fertilization, sperm and egg bundles collected from all colonies were mixed together in $20 \mathrm{l}$ holding containers.

To reliably measure the metabolic rate at each developmental stage, each embryo or planula was removed from the $20 \mathrm{l}$ holding container and washed in Milli- pore-filtered seawater (MFSW, 0.2- $\mu$ m pore diameter) in a Petri dish. The embryo was then placed in our original acrylic micro-chamber (cylindrical hole: $1 \mathrm{~mm}$ radius $\times 2 \mathrm{~mm}$ high) filled with MFSW $(6.28 \mu \mathrm{l})$. This system was optimized to measure the $\mathrm{O}_{2}$ consumption rate of a single embryo or planula of Acropora intermedia. The chamber was placed in a water bath (Personal-11, Taitec) maintained at $27 \pm 0.08^{\circ} \mathrm{C}$ (mean \pm $\mathrm{SD})$. The metabolic rate of a single embryo or planula was measured as the rate of $\mathrm{O}_{2}$ consumption using the optical $\mathrm{O}_{2}$-sensing system (Fibox3, PreSens). The sensor was calibrated against a zero solution $(0.01 \mathrm{M}$ sodium sulfate) and air-saturated MFSW (Nakaya et al. 2003) before the analysis of the various developmental stages. Data were collected using a personal computer and converted into absolute values. The rate of change $\left(V_{\mathrm{O} 2}\right)$ in the dissolved $\mathrm{O}_{2}$ concentration was calculated using simple linear regression $\left(\mathrm{r}^{2}>0.9\right)$. We measured $V_{\mathrm{O} 2}$ over the course of 6.5 to $7 \mathrm{~min}$ and created the linear regression using data from the third to sixth min (3 min total), during which oxygen consumption was stable. The chamber was wrapped in aluminum foil during measurement. Control values were measured for 10 min using a chamber filled with MFSW alone. Each value for $\mathrm{O}_{2}$ consumption is expressed as the mean $\pm \mathrm{SD} \times 10^{-5} \mathrm{ml} \mathrm{O}_{2}$ egg/embryo/planula ${ }^{-1} \mathrm{~h}^{-1}$ at $27^{\circ} \mathrm{C}$. After measurement, the embryo was returned to the 201 holding container.

Differences in $\mathrm{O}_{2}$ consumption across developmental stages were analyzed using the Kruskal-Wallis test with a correction for ties. Where significant differences were detected, Dunn's multiple comparison was used to determine which group(s) differed.

\section{RESULTS AND DISCUSSION}

As a general observation and a useful baseline, we noted that embryogenesis in Acropora intermedia was similar to that in other Acropora spp. (Fig. 1) (Hayashibara et al. 1997, Okubo \& Motokawa 2007). The lowest rate of $\mathrm{O}_{2}$ consumption was measured in unfertilized eggs at $0.97 \pm 0.26 \times 10^{-5} \mathrm{ml} \mathrm{O}_{2} \mathrm{egg}^{-1} \mathrm{~h}^{-1}$ at $27^{\circ} \mathrm{C}$ (Figs. 1A \& 2). After fertilization, $\mathrm{O}_{2}$ consumption in the fertilized eggs increased to $1.48 \pm 0.17 \times 10^{-5} \mathrm{ml} \mathrm{O}_{2}$ embryo $^{-1} \mathrm{~h}^{-1}$ at $27^{\circ} \mathrm{C}$. Moreno \& Hoegh-Guldberg (1999) also reported that respiration in 3 congeneric seastars (Patiriella, Verrill) increases soon after fertilization. After the first cleavage and the formation of a heart-shaped zygote at $2 \mathrm{~h}$ (Figs. 1B \& 2), $\mathrm{O}_{2}$ consumption remained at the same level as in fertilized eggs until the prawn chip blastula stage (Dunn's multiple comparison, $\mathrm{p}>0.05$, Figs. $1 \mathrm{~B}-\mathrm{I} \& 2$ ). However, $\mathrm{O}_{2}$ consumption began to increase in the bowl-shaped blastula (Figs. $1 \mathrm{~J}, \mathrm{~K} \& 2$ ), which requires the formation of 2 

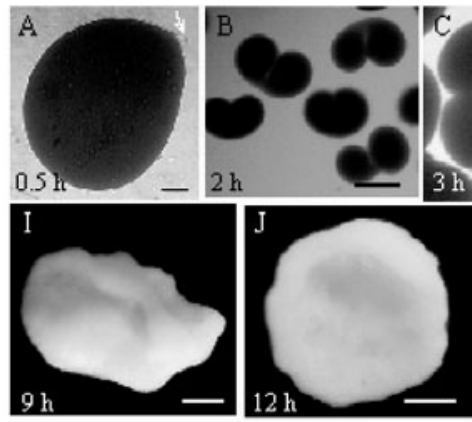
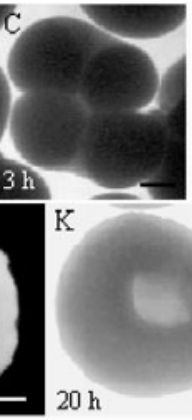
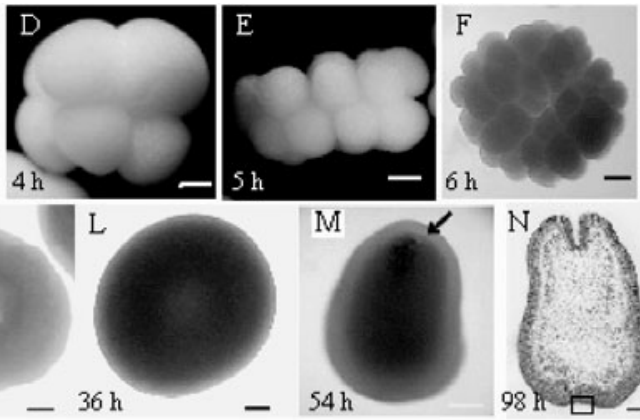

$5 \mathrm{~h}$

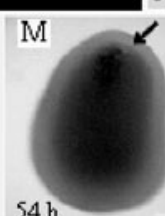

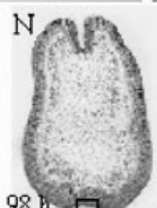

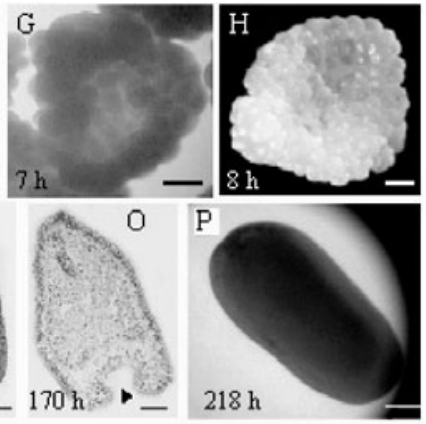

Fig. 1. Acropora spp. Embryogenesis (data from Okubo \& Motokawa 2007). (A) External view of the egg and polar body (white arrow). Fertilization may not have occurred. (B) 2 cell stage. (C) 4 cell stage. (D) 8 cell stage. (E) Side view of the 16 cell stage. (F) 32 cell stage. (G) Morula stage. (H) Prawn chip blastula. (I) Smoothing of the cell surface. (J) Gastrulation begins as the blastula rolls inward. (K) Gradual thickening of the blastula. (L) Blastocoel is translucent and the blastopore is not externally visible. (M) Mouth forms at the animal pole during the planula stage. (N) Invagination of the outer germ layer and formation of the aboral concavity. Square indicates the aboral region with numerous spirocysts at this time. (O) Aboral concavity (arrowhead) becomes more conspicuous. (P) Elongated planula. Numbers indicate hours post-spawning. Scale bars $=100 \mu \mathrm{m}(\mathrm{A}, \mathrm{C}-\mathrm{H}, \mathrm{J}-\mathrm{P}), 50 \mu \mathrm{m}(\mathrm{B}, \mathrm{I})$

germ layers and corresponds to the beginning of gastrulation (Okubo \& Motokawa 2007). The blastocoel was formed (Fig. 1H,I, possible cavitation in coral) and was gradually filled with yolk and ingressing cells (Fig. 1J-L). In the lecithotrophic larvae of the sea urchin Heliocidaris erythrogramma, a transient spike in the metabolic rate is observed in late gastrulation (Hoegh-Guldberg \& Emlet 1997). In mammals such as mice (Houghton et al. 1996, Ottosen et al. 2007), pigs (Sturmey \& Leese 2003), cattle (Thompson et al. 1996), and humans (Butcher et al. 1998), $\mathrm{O}_{2}$ consumption is relatively constant from the one-cell to morula stages, but sharply increases at the blastocyst stage, when the first cell differentiation event in mammalian embryogenesis segregates the inner cell mass lineage from the trophectoderm. These results suggest that the metabolic rate increases during major developmental changes such as gastrulation.

$\mathrm{O}_{2}$ consumption peaked at the teardrop-shaped planula stage $\left(6.04 \pm 2.03 \times 10^{-5} \mathrm{ml} \mathrm{O}_{2}\right.$ planula $^{-1} \mathrm{~h}^{-1}$ at $27^{\circ} \mathrm{C}$, Figs. $1 \mathrm{M} \& 2$ ). This rate was statistically greater than those of all developmental stages before the round-shaped gastrula and after $6 \mathrm{~d}$ of development (Kruskal-Wallis test, $H=94.7, \mathrm{p}<0.001$; Dunn's multiple comparison: $\mathrm{p}<0.05$ for each stage from unfertilized egg to bowl-shaped blastula versus teardropshaped planula stage; $\mathrm{p}<0.05$ for teardrop-shaped planula stage versus all stages from 7 to $20 \mathrm{~d}$ old planula). At this stage, the planulae swam actively, especially in the vertical plane, and the aboral region

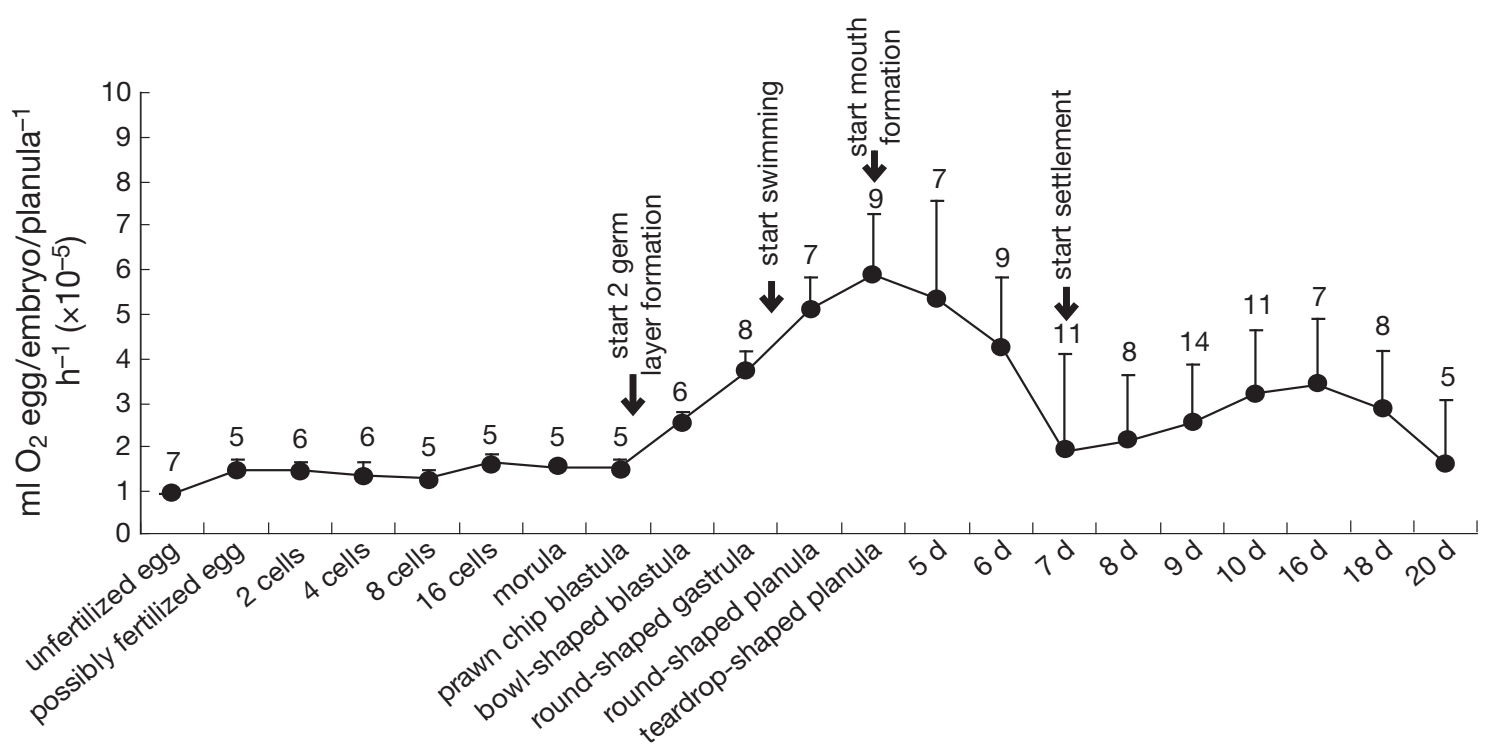

Fig. 2. Acropora intermedia. $\mathrm{O}_{2}$ consumption of a single embryo/planula (mean $\pm \mathrm{SD}$ ). Numbers indicate replicates; vertical lines indicate $+1 \mathrm{SD}$ 
became thicker and slightly concave in preparation for settlement (Fig. 1N) (Okubo \& Motokawa 2007).

In echinoderms, specifically the sea star Dendraster excentricus and the sea urchins Strongylocentrotus purpuratus and Strongylocentrotus franciscanus, the rate of $\mathrm{O}_{2}$ consumption peaks abruptly at hatching and then decreases sharply approximately $5 \mathrm{~h}$ after the beginning of hatching, returning to a level similar to that just prior to hatching (Hoegh-Guldberg \& Manahan 1995). In Acropora planulae, however, such a dramatic change was not observed during the teardropshaped stage (Fig. 2) (Okubo \& Motokawa 2007), but the total lipid content decreases dramatically $5 \mathrm{~d}$ after spawning (Harii et al. 2007). These results suggest that vertical swimming behavior requires increased energy consumption. We observed that $\mathrm{O}_{2}$ consumption and energy use peaked during the stage characterized by vertical swimming (Fig. 1M,N). There are several explanations for this observation, including predator avoidance (Trager et al. 1994) and the need to locate a site with sufficient light intensity for growth after settlement (Mundy \& Babcock 1998). In addition, planulae change their vertical position in the water column to disperse over significant distances while buoyant (Arai et al. 1993, Szmant \& Meadows 2006). Although planulae are small, weak swimmers and cannot swim against horizontal currents, their ability to change the vertical position in the water column may have a significant influence on horizontal transport (Szmant \& Meadows 2006), as has been demonstrated in fish larvae (Weinstein et al. 1980, Kingsford \& Choat 1986, Dame \& Allen 1996, Bradbury \& Snelgrove 2001). Such behavior would increase larval survivorship and dispersal potential in the early life history of corals.

Beginning $5 \mathrm{~d}$ after spawning, $\mathrm{O}_{2}$ consumption decreased gradually (Fig. 2) and the planulae began to touch the substrate with their concave aboral ends, where numerous spirocysts required for substrate attachment were developing (Will 1909, Mariscal et al. 1977, Yamashita et al. 2003) (Fig. 1O,P). Seven days after spawning, the planulae began to settle, and $\mathrm{O}_{2}$ consumption decreased to levels observed in early developmental stages (Dunn's multiple comparison: $p>0.05$ for each stage from unfertilized egg to roundshaped gastrula versus each stage from 7 to $20 \mathrm{~d}$ old planula). In Acropora tenuis, the lipid content remains at $>60 \%$ in $5 \mathrm{~d}$ old planulae (Harii et al. 2007). The maximum settlement period for spawning corals is reported to be more than $78 \mathrm{~d}$ after spawning (Wilson \& Harrison 1998, Nishikawa et al. 2003, Nozawa \& Harrison 2005). These studies suggest that planulae slowly consume stored energy for crawling/settlement behavior and/or post-settlement growth and survivorship. Further studies of $\mathrm{O}_{2}$ consumption in settled polyps are required to clarify this issue.
Acknowledgements. We thank S. Uchida, M. Toda, H. Teruya, M. Nonaka, and M. Yanagisawa for their help and the Okinawa Churaumi Aquarium for financial support. We greatly thank H. Matsuda, T. Kikuchi and the JSPS GCOE program; Global Eco-Risk Management from Asian View Points of Yokohama National University for their support, N. Isomura, Y. Nozawa, A. Szmant, 3 anonymous reviewers and P. J. Edmunds for valuable comments regarding this study.

\section{LITERATURE CITED}

Arai T, Kato M, Heyward A, Ikeda Y, Iizuka Y, Murayama T (1993) Lipid composition of positively buoyant eggs of reef building corals. Coral Reefs 12:71-75

Bambot SB, Holavanahali R, Lakowicz JR, Carter GM, Rao G (1994) Phase fluorometric sterilizable optical oxygen sensor. Biotechnol Bioeng 43:1139-1145

> Ben-David-Zaslow R, Benayahu Y (2000) Biochemical composition, metabolism, and amino acid transport in planulalarvae of the soft coral Heteroxenia fuscescens. J Exp Zool 287:401-412

Bradbury IR, Snelgrove PVR (2001) Contrasting larval transport in demersal fish and benthic invertebrates: the roles of behaviour and advective processes in determining spetial pattern. Can J Fish Aquat Sci 58:811-828

Bryan PJ (2004) Energetic cost of development through metamorphosis for the seastar Mediaster aequalis (Stimpson). Mar Biol 145:293-302

Butcher L, Coates A, Martin KL, Rutherford AJ, Lees HJ (1998) Metabolism of pyruvate by the early human embryo. Biol Reprod 58:1054-1056

Chia FS, Buckland-Nicks J, Young CM (1984) Locomotion of marine invertebrate larvae: a review. Can J Zool 62: 1205-1222

Clark LCR Jr (1956) Monitor and control blood and tissue oxygen tension. Trans Am Soc Artif Intern Organs 2:41

Crisp DJ, Yule AB, White KN (1985) Feeding by oyster larvae - the functional response, energy budget, and a comparison with mussel larvae. J Mar Biol Assoc UK 65: 759-784

Dame RF, Allen DM (1996) Between estuaries and the sea. J Exp Mar Biol Ecol 200:169-185

> Harii S, Kayanne H (2003) Recruitment and adult distribution of brooding blue coral, Heliopora coerulea, at Ishigaki island, southwest of Japan. Coral Reefs 22:188-196

> Harii S, Nadaoka K, Yamamoto M, Iwao K (2007) Temporal changes in settlement, lipid content, and lipid composition of larvae of the spawning hermatypic coral Acropora tenuis. Mar Ecol Prog Ser 346:89-96

Hayashibara T, Ohike S, Kakinuma Y (1997) Embryonic and larval development and planula metamorphosis of four gamete-spawning Acropora (Anthozoa, Scleractinia). Proc 8th Intl Coral Reef Symp 2:1231-1236

Hoegh-Guldberg O, Emlet RB (1997) Energy use during the development of a lecithotrophic and aplanktotrophic echinoid. Biol Bull 192:27-40

$>$ Hoegh-Guldberg O, Manahan DT (1995) Coulometric measurement of oxygen consumption during development of marine invertebrate embryos and larvae. J Exp Biol 198: $19-30$

Holland DL (1978) Lipid reserves and energy metabolism in the larvae of benthic marine invertebrates. In: Sargent DC, Malins JR (eds) Biochemical and biophysical perspectives in marine biology. Academic Press, London, p 85-123 
Houghton FD, Thompson JG, Kennedy CJ, Leese HJ (1996) Oxygen consumption and energy metabolism of early mouse embryo. Mol Reprod Dev 44:476-485

Isomura N, Nishihira M (2001) Size variation of planulae and its effect on the lifetime of planulae in three pocilloporid corals. Coral Reefs 20:309-315

Kingsford MJ, Choat JH (1986) Influence of surface slicks on the distribution and onshore movements of small fish. Mar Biol 91:161-171

Lopes A, Greve T, Callesen H (2007) Quantification of embryo quality by respirometry. Theriogenology 67:21-31

Mariscal RN, McLean RB, Hand C (1977) The form and function of cnidarian spirocysts. 3. Ultrastructure of the thread and the function of spirocysts. Cell Tissue Res 178: $427-433$

Marsh AG, Leong PKK, Manahan DT (1999) Energy metabolism during embryonic development and larval growth of an Antarctic sea urchin. J Exp Biol 202:2041-2050

Moreno G, Hoegh-Guldberg O (1999) The energetics of development of 3 congeneric seastars (Patiriella Verrill, 1913) with different types of development. J Exp Mar Biol Ecol 235:1-20

Morgan SG (1995) The timing of larval release. In: McEdward L (ed) Ecology of marine invertebrate larvae. CRC Press, Boca Raton, FL, p 249-278

Mundy CN, Babcock RC (1998) Role of light intensity and spectrum quality in coral settlement: Implications for depth-dependent settlement? J Exp Mar Biol Ecol 223: 235-255

Nakaya F, Saito Y, Motokawa T (2003) Switching of metabolic-rate scaling between allometry and isometry in colonial ascidians. Proc R Soc Lond B Biol Sci 270:1105-1113

Nakaya F, Saito Y, Motokawa T (2005) Experimental allometry: effect of size manipulation on metabolic rate of colonial ascidians. Proc R Soc Lond B Biol Sci 272:1963-1969

Nishikawa A, Katoh M, Sakai K (2003) Larval settlement rates and gene flow of broadcast-spawning (Acropora tenuis) and planula-brooding (Stylophora pistillata) corals. Mar Ecol Prog Ser 256:87-97

Nozawa Y, Harrison PL (2005) Temporal settlement patterns of larvae of the broadcast spawning reef coral Favites chinensis and the broadcast spawning and brooding reef coral Goniastrea aspera from Okinawa, Japan. Coral Reefs 24:274-282

Okubo N, Motokawa T (2007) Embryogenesis in the ReefBuilding Acropora spp. Zool Sci 24:1169-1177

Okubo N, Taniguchi H, Motokawa T (2005) Successful meth-

Editorial responsibility: Peter Edmunds,

Northridge, California, USA ods for transplanting fragments of Acropora formosa and Acropora hyacinthus. Coral Reefs 24:333-342

Ottosen LDM, Hindkjaer J, Lindenberg S, Ingerslev HJ (2007) Murine pre-embryo oxygen consumption and developmental competence. J Assist Reprod Genet 24:359-365

Pechenik JA (1990) Delayed metamorphosis by larvae of benthic marine-invertebrates - does it occur? Is there a price to pay? Ophelia 32:63-94

Richmond RH (1987) Energetics, competency, and longdistance dispersal of planula larvae of the coral Pocillopora damicornis. Mar Biol 93:527-533

Sturmey RG, Leese HJ (2003) Energy metabolism in pig oocytes and early embryos. Reproduction 126:197-204

Szmant AM, Meadows MG (2006) Developmental changes in coral larval buoyancy and vertical swimming behavior: Implications for dispersal and connectivity. Proc 10th Int Coral Reef Symp 431-437

> Thompson JG, Partridge RG, Houghton FD, Cox CI, Leese HJ (1996) Oxygen uptake and carbohydrate metabolism by in vitro derived bovine embryos. J Reprod Fertil 106: 299-306

> Trager G, Achituv Y, Genin A (1994) Effects of prey escape ability, flow speed, and predator feeding mode on zooplankton capture by barnacles. Mar Biol 120:251-259

Underwood AJ, Keough MJ (2001) Supply-side ecology: the nature and consequences of variations in recruitment of intertidal organisms. In: Bertness MD, Gains SD, Hay ME (eds) Marine community ecology. Sinauer Associates, Sunderland, MA, p 183-200

Wallace CC, Dai CF (1997) Scleractinia of Taiwan (IV): Review of the Coral Genus Acropora from Taiwan. Zool Stud 36:288-324

Weinstein MP, Weiss SL, Hodson RG, Gerry LR (1980) Retention of three taxa of post larval fishes in an intensively flushed tidal estuary, Cape Fear River, North Carolina. Fish Bull US 78:419-436

Will L (1909) Die Klebkapseln der Aktinien und der Mechanismus ihrer Entladung. S.-B. Abh Naturf Ges Rostock, N. F. 1:65-103

Wilson JR, Harrison PL (1998) Settlement-competency periods of larvae of three species of scleractinian corals. Mar Biol 131:339-345

Yamashita K, Kawaii S, Nakai M, Fusetani N (2003) Larval behavioral, morphological changes, and nematocyte dynamics during settlement of actinulae of Tubularia mesembryanthemum, Allman 1871 (Hydrozoa: Tubulariidae). Biol Bull 204:256-269

Submitted: January 11, 2008; Accepted: April 30, 2008 Proofs received from author(s): August 18, 2008 